\title{
Choroidal and Ciliary Body Melanoma pT4e TNM Finding v8
}

National Cancer Institute

\section{Source}

National Cancer Institute. Choroidal and Ciliary Body Melanoma pT 4e TNM Finding v8. NCI Thesaurus. Code C140651.

Choroidal and ciliary body melanoma, any tumor size category with extraocular extension more than $5 \mathrm{~mm}$ in largest diameter. (from AJCC 8th Ed.) 